\title{
Pengaruh Metode Penemuan Terbimbing Berbantuan Media Realita terhadap Motivasi Berprestasi dan Hasil Belajar Matematika Siswa
}

\author{
N. K. Ayu Erawati ${ }^{*}$, A.A.I.N Marhaeni², Sariyasa ${ }^{3}$ \\ 1,2,3 Program Studi Pendidikan Dasar, Program Pascasarjana Universitas Pendidikan Ganesha Singaraja, Indonesia
}

\section{ARTICLEIN}

$\mathrm{F} \mathrm{O}$

Article history:

Received 17

November 2017

Received in revised

form

12 Desember 2017

Accepted 15 Januari 2018

Available online 20

Februari 2018

\section{Kata Kunci:}

hasil belajar, metode penemuan

terbimbing, motivasi

berprestasi

Keywords:

learning outcomes,

guided discovery

method,

achievement

motivation.

\begin{abstract}
A B S TR A K
Penelitian ini bertujuan untuk mengetahui pengaruh metode penemuan terbimbing berbantuan media realita terhadap motivasi berprestasi dan hasil belajar matematika siswa kelas V SD Gugus XV Kecamatan Buleleng, Kabupaten Buleleng. Penelitian ini menggunakan pendekatan eksperimen semu dengan pola dasar single factor independent group design. Populasi dalam penelitian ini sebanyak 210 orang siswa. Sampel penelitian berjumlah 73 orang siswa ditentukan dengan teknik random sampling. Data motivasi berprestasi siswa dikumpulkan dengan kuisioner dan data hasil belajar matematika dikumpulkan dengan tes. Data dianalisis menggunakan MANOVA berbantuan SPSS 16.00 for windows. Hasil penelitian menunjukkan bahwa: pertama, motivasi berprestasi siswa yang mengikuti metode penemuan terbimbing berbantuan media realita secara signifikan lebih baik daripada siswa yang mengikuti pembelajaran konvensional $(F=1687,145 ; p<0,05)$; kedua, hasil belajar matematika siswa yang mengikuti metode penemuan terbimbing berbantuan media realita secara signifikan lebih baik daripada siswa yang mengikuti pembelajaran konvensional $(F=159,515 ; p<0,05)$; ketiga, secara simultan motivasi berprestasi dan hasil belajar matematika antara siswa yang mengikuti metode penemuan terbimbing berbantuan media realita secara signifikan lebih baik daripada siswa yang mengikuti pembelajaran konvensional.
\end{abstract}

\section{A B S T R A C T}

This study aims to determine the effect of guided discovery method assisted media reality to achievement motivation and mathematics learning outcomes of students of grade V SD Gugus XV Buleleng District, Buleleng District. This research uses a pseudo experimental approach with the basic pattern of single factor independent group design. The population in this study as many as 210 students. The sample of the study amounted to 73 students determined by random sampling technique. Student achievement motivation data were collected by questionnaire and mathematics learning result data was collected by test. Data were analyzed using MANOVA with SPSS 16.00 for windows. The results showed that: first, achievement motivation of students who followed guided discovery method with media aid of reality was significantly better than students who followed conventional learning ( $F=1687,145 ; p<0,05)$; secondly, the result of the students' mathematics learning that follows the guided discovery method with the reality media is significantly better than the students who follow the conventional learning ( $F=159,515 ; p<0,05)$; thirdly, simultaneously achievement motivation and mathematics learning outcomes between students who follow guided discovery methods with real-time media are significantly better than students who follow conventional learning.

\footnotetext{
* Corresponding author.

E-mail addresses: ayu.erawati@pasca.undiksha.ac.id (Ayu Erawati)
} 


\section{Pendahuluan}

Belajar matematika adalah pembentukan pola pikir dalam pemahaman suatu pengertian maupun penalaran dalam suatu hubungan. Dalam Kurikulum Tingkat Satuan Pendidikan (KTSP) (Depdiknas 2006) mata pelajaran Matematika bertujuan agar peserta didik memiliki kemampuan sebagai berikut: (1) Memahami konsep matematika, menjelaskan keterkaitan antar konsep dan mengaplikasikan konsep alogaritma, secara luwes, akurat, efesien, dan tepat dalam pemecahan masalah; (2) Menggunakan penalaran pada pola dan sifat, melakukan manipulasi matematika dalam membuat generalisasi, menyusun bukti, atau menjelaskan gagasan dan pernyataan matematika; (3) memecahkan masalah yang meliputi kemampuan memahami masalah, merancang model dan menapsirkan solusi yang diperoleh; (4) mengkomunikasikan gagasan dengan simbol, tabel, diagram, atau media lain untuk memperjeas keadaan atau masalah; (5) memiliki sikap menghargai kegunaan matematika dalam kehidupan yaitu, memiliki rasa ingin tau, perhatian dan minat dalam mempelajari matematika, serta sikap ulet dan percaya diri dalam pemecahan masalah.

Salah satu upaya untuk mempermudah pemahaman materi matematika diperlukan media pembelajaran. Media yang relevan dalam pembelajaran matematika dalah media realita. Rusman (2005: 2) menyatakan bahwa media realia yaitu semua media nyata didalam ruang kelas, tetapi dapat digunakan sebagai sesuatu kegiatan observasi pada lingkungannya. Yang dimaksud dengan benda nyata sebagai media adalah alat penyampaian informasi yang berupa benda atau obyek yang sebenarnya atau asli dan tidak mengalami perubahan yang berarti.

Pembelajaran dengan menggunakan media realita memungkinkan dapat memotivasi siswa untuk belajar. Motivasi merupakan dorongan yang datang dari diri seseorang yang berupa keinginan untuk berprestasi, harapan dan sebagainya. Motivasi berprestasi sangat penting dimiliki oleh setiap siswa, siswa yang memiliki motivasi berprestasi tinggi digambarkan dengan pusat pemikiran yang tinggi terhadap perjuangan prestasi dan sebaliknya motivasi berprestasi rendah digambarkan dengan pusat pemikiran yang rendah terhadap perjuangan prestasi.

Menurut Jumi Rianti, dkk (2017: 3) adalah suatu dorongan dari dalam diri yang dapat menimbulkan perubahan tingkah laku atau perbuatan seseorang sebagai penyemangat dalam belajar untuk selalu meraih prestasi. McClelland dalam The Encyclopedia Dictionary of Psychology yang disusun oleh Hare dan Lamb (Djaali, 2008:103) mengungkapkan bahwa motivasi berprestasi merupakan motivasi yang berhubungan dengan pencapaian beberapa standar kepandaian atau standar keahlian.

Berdasarkan kajian teori di ata yang meneliti tentang motivasi berprestasi, dapat dirumuskan bahwa motivasi berprestasi adalah suatu dorongan yang berhubungan dengan usaha bagaimana melakukan sesuatu dengan sebaik-baiknya atas dasar kompetensi yang sehat dan bertanggungjawab untuk mencapai hasil yang maksimal berdasarkan atas dasar keunggulan.

Namun kenyataan menunjukkan bahwa, masih rendahnya motivasi siswa dalam mengikuti pembelajaran matematika yang berdampak pada rendahnya hasil belajar siswa. Siswa memandang bahwa matematika merupakan mata pelajaran yang sangat sulit, sehingga siswa kurang termotivasi dalam pembelajaran matematika. Selain itu juga, rendahnya hasil belajar matematika disebabkan oleh pengemasan proses pembelajaran. Selain itu, peneliti juga melakukan observasi dan wawancara dengan wali kelas V di masing-masing Sekolah Dasar Gugus XV mengenai rendahnya motivasi berprestasi dan hasil belajar matematika siswa.

Proses pembelajaran masih didasarkan pada asumsi bahwa pengetahuan dapat dipindahkan secara utuh dari pikiran guru ke pikiran siswa belum sebagai keterampilan berproses dan membangun pengetahuan yang lebih bermakna. Pada cara pembelajaran ceramah, guru hanya mengaktifkan ingatan jangka pendek siswa dan tidak memotivasi siswa untuk aktif dalam pembelajaran, sehingga siswa tidak memahami apa yang telah diajarkan.

Dalam proses pembelajaran, khususnya dalam pembelajaran Matematika, guru masih menggunakan pembelajaran konvesional yang menjadi pilihan utama dalam pembelajaran. Pembelajaran konvensional dalam pembelajaran matematika tidak memberikan kesempatan kepada siswa untuk berpikir sendiri, menemukan konsep baru, kreatif dalam pembelajaran. Rendahnya motivasi siswa dalam pembelajaran khususnya pembelajaran matematika yang pada akhirnya berdampak pada rendahnya hasil belajar matematika siswa dapat diartikan kurang efektifnya proses pembelajaran. Penyebabnya dapat berasal dari siswa, guru maupun sarana dan prasarana yang ada, minat dan motivasi siswa yang rendah, kinerja guru yang rendah serta sarana dan prasarana yang kurang memadai akan menyebabkan pembelajaran menjadi kurang efektif.

Salah satu metode pembelajaran yang mungkin tepat digunakan dalam pembelajaran matematika adalah dengan menggunakan metode penemuan terbimbing. Metode penemuan terbimbing adalah suatu metode pembelajaran yang menghendaki siswa menemukan ide-ide dalam proses penemuan, siswa 
mendapat bimbingan dari guru baik berupa petunjuk secara lisan maupun petunjuk tertulis yang dituangkan dalam bentuk lembar kerja siswa. Menurut Sund dalam (Suryosubroto, 2009:179), discovery adalah proses mental dimana siswa mengasimilasikan sesuatu konsep atau sesuatu prinsip. Proses mental itu misalnya : mengamati, menggolong-golongkan, membuat dugaan, menjelaskan, mengukur, membuat kesimpulan, dan sebagainya.

Sedangakan menurut Jerome Bruner (dalam Markaban, 2008:9), penemuan adalah suatu proses. Sejalan dengan pendapat di atas, Bell (dalam Dian Wijayanti, 2016) menyatakan bahwa pembelajaran dengan metode penemuan terjadi sebagai hasil dari siswa memanipulasi, menyusun, dan mentransformasi informasi sehingga mereka menemukan informasi baru. Proses penemuan dapat menjadi kemampuan umum melalui latihan pemecahan masalah, praktek membentuk dan menguji hipotesis. Metode penemuan merupakan metode belajar yang dipopulerkan oleh Bruner. Bruner (dalam Marhaeni, 2013:28) menganggap bahwa belajar penemuan sesuai dengan pencarian pengetahuan secara aktif oleh manusia, dan dengan sendirinya memberi hasil yang paling baik.

Dengan demikian didalam pandangan Bruner, belajar dengan penemuan adalah belajar untuk menemukan, dimana seorang siswa dihadapkan dengan suatu masalah atau situasi yang tampaknya ganjil sehingga siswa dapat mencari jalan pemecahan. Sejalan dengan pendapat di atas, Setiawan (2010:32) berpendapat bahwa metode penemuan terbimbing sebagai suatu metode mengajar yang bermanfaat untuk pembelajaran matematika. Metode penemuan terbimbing menempatkan guru sebagai fasilitator, guru membimbing siswa dimana ia diperlukan. Dengan metode penemuan terbimbing siswa didorong untuk berpikir sendiri, menganalisis sendiri sehingga dapat menemukan prinsip dan konsep berdasarkan apa yang disampaikan guru. Metode penemuan terbimbing menghadapkan siswa pada situasi dimana ia bebas menyelidiki dan menarik kesimpulan. Dengan metode penemuan terbimbing, siswa didorong untuk belajar sebagian besar melalui keterlibatan aktif mereka sendiri dengan konsep-konsep dan prinsipprinsip. Namun dalam proses penemuan ini, siswa mendapat bantuan atau bimbingan dari guru agar mereka lebih terarah sehingga proses pelaksanaan pembelajaran dan tujuan pembelajaran dapat tercapai dengan baik.

Metode penemuan terbimbing memberikan peluang dan kesempatan kepada siswa untuk lebih memahami dan menemukan hal baru. Konsep belajar penemuan pada pembelajaran matematika mengedepankan aspek berpikir kritis, logis, linier, dan teratur. Metode penemuan terbimbing dapat meningkatkan motivasi belajar siswa karena siswa dilibatkan secara aktif dalam pembelajaran. Penggunaaan media dalam pembelajaran sangat penting, karena dengan adanya media dalam pembelajaran akan dapat meiningkatkan motivasi dalam belajar, siswa menjadi tertarik dalam pembelajaran.

Tahapan kegiatan metode penemuan terbimbing yaitu 1) penyajian masalah, 2) pengumpulan dan verivikasi data, 3) pengumpulan data melalui eksperimen, 4) perumusan dan pengolahan data, 5) analisis proses penemuan. Melalui penerapan metode penemuan terbimbing berbantuan media realita diharapkan dapat meningkatkan motivasi berprestasi dan hasil belajar matematika siswa. Pembelajaran yang konkret, menarik, serta mandiri dapat membantu siswa dalam memahami konsep dengan baik dengan melakukan penemuan sendiri dalam materi darah. Maka perlu dilakukan penelitian dengan judul "Pengaruh Metode Penemuan Terbimbing Berbantuan Media Realita Terhadap Motivasi Berprestasi dan Hasil Belajar Matematika Suswa Kelas V SD Gugus XV Kecamatan Buleleng Kabupaten Buleleng.

Mengingat masalah tersebut sangat penting, maka dilakukan penelitian dengan tujuan: 1) Untuk menganalisis dan mendeskripsikan perbedaan motivasi berprestasi antara siswa yang mengikuti pembelajaran dengan metode penemuan terbimbing berbantuan media realita dan siswa yang mengikuti pembelajaran konvensional pada siswa kelas V SD, 2)Untuk menganalisis dan mendeskripsikan perbedaan hasil belajar matematika antara siswa yang mengikuti pembelajaran dengan metode penemuan terbimbing berbantuan media realita dan siswa yang mengikuti pembelajaran konvensional pada siswa kelas V SD, 3) Untuk menganalisis dan mendeskripsikan perbedaan motivasi berprestasi dan hasil belajar matematika secara simultan antara siswa yang mengikuti pembelajaran dengan metode penemuan terbimbing berbantuan media realita dan siswa yang mengikuti pembelajaran konvensional pada siswa kelas V SD

\section{Metode}

Penelitian ini dilaksanakan di Gugus XV Tahun Pelajaran 2017/2018. Jenis penelitian ini dikategorikan penelitian eksperimen semu (quasy exsperiment). Desain penelitian adalah single factor independent group design dengan menggunakan kelompok eksperimen (metode penemuan terbimbing berbantuan media realita) dan kelompok kontrol (pembelajaran konvesional). Populasi dalam penelitian ini adalah seluruh siswa kelas V Gugus XV Kecamatan Buleleng Kabupaten Buleleng.Teknik pengambilan 
sampel dengan random sampling. Hasil pemilihan sampel menetapkan kelas V SD N 2 Kalibukbuk dengan siswa sejumlah 34 orang sebagai kelompok eksperimen yang menerapkan metode penemuan terbimbing berbantuan media realita dan kelas V SD N 4 Kalibukbuk dengan siswa sebanyak 39 orang sebagai kelompok kontrol yang menerapkan pembelajaran konvensional. Variabel bebas dalam penelitian ini berupa metode penemuan terbimbing berbantuan media realita dan pembelajaran konvensional sedangkan variabel terikatnya berupa motivasi berprestasi dan hasil belajar matematika. Teknik pengumpulan data yang digunakan dalam penelitian ini adalah teknik tes dan non-tes. Teknik tes digunakan untuk mengambil data hasil belajar matematika, dalam penelitian ini tes yang digunakan adalah tes objektif dengan bentuk pilihan ganda dan teknik non-tes dalam penelitian ini dengan menggunakan lembar kuesioner motivasi berprestasi siswa dengan modifikasi dari skala Likert. Analisis data yang digunakan pada penelitian ini analisis statistik deskriptif, yang artinya bahwa data dianalisis dengan menghitung nilai rata-rata, modus, median, standar deviasi, varian, skor maksimum, dan skor minimum. Dalam penelitian ini data disajikan dalam bentuk grafik histogram. Teknik yang digunakan untuk menganalisis data guna menguji hipotesis penelitian adalah MANOVA. Sebelum dilakukan analisis data, maka dilakukan uji normalitas sebaran data dengan menggunakan uji Kolmogorov-smirnov, uji homogenitas varians dengan uji Levene's, dan uji korelasi antar variabel terikat (kolinieritas) dengan menggunakan product moment.

\section{Hasil dan Pembahasan}

Hasil pembahasan dalam penelitian ini adalah sebagai berikut: 1) Motivasi berprestasi siswa yang mengikuti metode pembelajaran penemuan terbimbing berbantuan media realita

Data tentang motivasi berprestasi yang mengikuti pembelajaran dengan metode pembelajaran penemuan terbimbing berbantuan media realita $\left(A_{1} Y_{1}\right)$ menunjukkan skor minimum $=181$, skor maksimum $=197$, banyak kelas interval $=6$, panjang kelas interval $=3$, rata-rata $=189,65$, median $=190,5$, standar deviasi $=4,72$, dan varians $=22,24$, rentangan $=16, \mathrm{n}=34$. Jika dilihat dari rata-rata (mean) $=$ 189,65 dan dikonversikan ke dalam tabel di atas, dapat diketahui bahwa kencederungan data motivasi berprestasi siswa yang mengikuti metode pembelajaran penemuan terbimbing berbantuan media realita masuk dalam kategori sangat tinggi. 2) Motivasi berprestasi siswa yang mengikuti pembelajaran konvensional Data tentang motivasi berprestasi yang mengikuti pembelajaran dengan pembelajaran konvensional $\left(\mathrm{A}_{2} \mathrm{Y}_{1}\right)$ menunjukkan skor minimum $=135$, skor maksimum $=151$, banyak kelas interval $=6$, panjang kelas interval $=3$, rata-rata $=143,05$, median $=142$, standar deviasi $=4,94$, dan varians $=24,37$, rentangan $=16, \mathrm{n}=39$. Jika dilihat dari rata-rata $($ mean $)=143,05$ dan dikonversikan ke dalam tabel di atas, dapat diketahui bahwa kencederungan data motivasi berprestasi siswa yang mengikuti metode pembelajaran konvensional masuk dalam kategori tinggi. 3) Perbandingan kecendrungan kualitas motivasi berprestasi siswa yang mengikuti pembelajaran dengan metode penemuan terbimbing berbantuan media realita dan siswa yang mengikuti pembelajaran konvensional 4) Kencederungan data motivasi berprestasi siswa yang mengikuti metode pembelajaran penemuan terbimbing berbantuan media realita dengan rerata 189,65 masuk dalam kategori sangat tinggi dan yang megikuti metode pembelajaran konvensional dengan rerata 143,05 masuk dalam kategori tinggi.

Maka, dilihat dari kecenderungan data motivasi berprestasi dapat disimpulkan bahwa motivasi berprestasi siswa yang mengikuti metode pembelajaran penemuan terbimbing berbantuan media realita lebih baik daripada motivasi berprestasi siswa yang mengikuti pembelajaran konvensional. 1) Hasil belajar matematika siswa yang mengikuti pembelajaran dengan metode penemuan terbimbing berbantuan media realita (A1Y2). 2) Data tentang hasil belajar matematika yang mengikuti pembelajaran dengan metode pembelajaran penemuan terbimbing berbantuan media realita mempunyai rentangan $=$ $24, \mathrm{n}=34$, skor minimum $=73$, skor maksimum $=97$, banyak kelas interval $=7$, panjang kelas interval $=4$, rata-rata $=82,65$, median $=83$, standar deviasi $=6,41$, dan varians $=41,14$. Jika dilihat dari rata-rata (mean) $=82,65$ dan dikonversikan ke dalam tabel di atas, dapat diketahui bahwa kencederungan data data hasil belajar matematika siswa yang mengikuti metode pembelajaran penemuan terbimbing berbantuan media realitamasuk dalam kategori sangat tinggi. 3) Hasil belajar matematika siswa yang mengikuti pembembelajaran konvensional (A2Y2). 4) Data tentang hasil belajar matematika yang mengikuti pembelajaran dengan metode pembelajaran konvensional mempunyai rentangan $=37, \mathrm{n}=39$, skor minimum $=43$, skor maksimum $=80$, banyak kelas interval $=6$, panjang kelas interval $=7$, rata-rata $=$ 59.31 , median $=60$, standar deviasi $=8,95$, dan varians $=80,17$. Jika dilihat dari rata-rata $($ mean $)=59,31$ dan dikonversikan ke dalam tabel di atas, dapat diketahui bahwa kencederungan data hasil belajar matematika siswa yang mengikuti metode pembelajaran konvensional masuk dalam kategori tinggi. 5) Perbandingan kecendrungan kualitas hasil belajar matematika siswa yang mengikuti pembelajaran dengan metode penemuan terbimbing berbantuan media realita dan siswa yang mengikuti pembelajaran 
konvensional. 6) Kencederungan data hasil belajar matematika siswa yang mengikuti metode pembelajaran penemuan terbimbing berbantuan media realita dengan rerata $=82,65$ masuk dalam kategori sangat tinggi dan yang megikuti pembelajaran dengan pembelajaran konvensional dengan rerata $=59,31$ masuk dalam kategori tinggi. Maka, dilihat dari kecenderungan data hasil belajar siswa tersebut dapat disimpulkan bahwa hasil belajar matematika siswa yang mengikuti metode pembelajaran penemuan terbimbing berbantuan media realita lebih baik daripada hasil belajar siswa yang mengikuti pembelajaran konvensional.

\section{Perbedaan motivasi berprestasi antara siswa yang mengikuti pembelajaran dengan metode penemuan terbimbing berbantuan media realita dan siswa yang mengikuti pembelajaran konvensional}

Berdasarkan hasil temuan dalam penelitian ini bahwa motivasi berprestasi memiliki nilai F sebesar $\mathbf{1 6 8 7 , 1 4 5}$ dengan nilai signifikansi 0,000 atau lebih kecil dari 0,05. Ini menunjukan bahwa nilai $\mathrm{F}$ pada variabel terikat motivasi berprestasi signifikan. Ini bermakna bahwa terdapat perbedaan motivasi berprestasi antara siswa yang mengikuti pembelajaran dengan metode penemuan terbimbing dengan siswa yang mengikuti pembelajaran konvensional.

Temuan penelitian ini didukung oleh penelitian Sumbogo (2015) yang hasil penelitiannya menujkukkan bahwa peningkatan motivasi belajar siswa yang memperoleh metode penemuan terbimbing lebih baik daripada siswa yang memperoleh pembelajaran konvensional

Pembelajaran yang menggunakan metode penemuan terbimbing berbantuan media realita diasumsikan memberikan sumbangan yang cukup berarti bagi siswa dalam proses belajar, karena metode penemuan terbimbing dapat merangsang siswa untuk aktif, mandiri, kreatif dalam belajarnya sehingga suasana belajarnya menjadi menyenangkan. Pembelajaran matematika dengan metode penemuan terbimbing memberikan kesempatan yang cukup luas kepada siswa untuk menemukan sendiri atau mengalami proses mental sendiri, sehingga siswa dapat belajar dengan menyenangkan.

Metode penemuan terbimbing memberikan suasana yang berbeda yang memungkinkan siswa untuk belajar lebih aktif dengan bimbingan guru, sehingga dalam pembelajaran terjadi komunikasi multi arah yang dapat membangkitkan semangat dan motivasi siswa untuk belajar. Dengan bantuan media realita dalam pembelajaran matematika dapat memberikan gambaran secara jelas kepada siswa sehingga siswa merasa semangat dan termotivasi dalam pembelajaran matematika. Pembelajaran yang menggunakan metode penemuan terbimbing berbantuan media realita lebih mengaktifkan siswa, karena siswa terlibat dalam aktivitas mental, mempunyai pengalaman yang langsung dan bermakna dalam belajarnya sehingga dapat menumbuhkan motivasi siswa. Pembelajaran konvensional, cenderung hanya guru yang berperan aktif (teacher centred), siswa hanya sebagai pendengar saja sehingga pembelajaran terkesan pasif. Siswa sering merasa bosan dalam mengikuti pelajaran. Hal ini menyebabkan siswa kurang termotivasi dalam belajar, kurang inisiatif dan kurangnya kreativitas siswa. Pembelajaran konvensional lebih menekankan pada pembelajaran yang terjadi hanya satu arah (teacher centred) tidak multi arah.

Dengan demikian, dapat disimpulkan bahwa terdapat perbedaan Motivasi Berprestasi antara kelompok siswa yang mengikuti pembelajaran dengan metode penemuan terbimbing berbantuan media realita dengan kelompok siswa yang mengikuti pembelajaran konvensional.

\section{Perbedaan hasil belajar matematika antara siswa yang mengikuti pembelajaran dengan metode penemuan terbimbing berbantuan media realita dan siswa yang mengikuti pembelajaran konvensional}

Berdasarkan temuan dalam penelitian ini bahwa hasil belajar matematika memiliki nilai F sebesar 159,515 dengan nilai signifikansi 0,000 atau lebih kecil dari 0,05. Ini menunjukan bahwa nilai $F$ pada variabel terikat hasil belajar matematika signifikan. Ini bermakna bahwa terdapat perbedaan hasil belajar matematika yang signifikan antara kelompok siswa yang mengikuti pembelajaran dengan metode pembelajaran penemuan terbimbing berbantuan media realita dengan kelompok siswa yang mengikuti pembelajaran konvensional.

Penelitian lain yang mendukung temuan ini adalah penelitian yang dilakukan oleh Ni Made Rai Sri Artini, dkk (2015) yang hasil penelitiannya menunjukkan bahwa terdapat perbedaan hasil belajar IPA siswa yang mengikuti pembelajaran dengan metode penemuan terbimbing dengan kelompok siswa yang mengikuti pembelajaran konvensional. Sri Yuni, dkk (2016) yang hasil penelitianya menunjukkan bahwa penerapan metode penemuan terbimbing memberikan pengaruh yang tinggi terhadap hasil belajar siswa pada pembelajaran simetri di kelas IV Sekolah Dasar Negeri 36 Pontianak Selatan. Rudianto, dkk (2015) yang hasil penelitiannya juga mendukung keberhasilan pengaruh metode penemuan terbimbing dalam pembelajaran, yang hasil penelitiannya menunjukkan bahwa penerapan metode penemuan terbimbing 
memberikan pengaruh yang tinggi terhadap hasil belajar matematika siswa SMPK Abdi Wacana Pontianak.

Pembelajaran dengan metode penemuan terbimbing menghendaki siswa menemukan ide-ide dalam proses penemuan, siswa mendapat bimbingan dari guru baik berupa petunjuk secara lisan maupun petunjuk tertulis yang dituangkan dalam bentuk lembar kerja siswa. Pembelajaran dengan metode penemuan terbimbing melibatkan proses mental dimana siswa mengasimilasikan sesuatu konsep atau sesuatu prinsip. Proses mental itu misalnya : mengamati, menggolong-golongkan, membuat dugaan, menjelaskan, mengukur, membuat kesimpulan, dan sebagainya.Belajar dengan metode penemuan terbimbing adalah belajar untuk menemukan, dimana seorang siswa dihadapkan dengan suatu masalah atau situasi yang tampaknya ganjil sehingga siswa dapat mencari jalan pemecahan.

Sementara pada pembelajaran konvensional, guru memiliki kecenderungan sebagai pemegang otoritas pembelajaran. Komunikasi yang terjadi lebih banyak satu arah dan penggunaan metode ceramah menjadi sangat dominan. Selama proses pembelajaran, siswa kurang aktif sehingga pembelajaran kurang kondusif. Pengembangan sosialisasi siswa, hubungan antar sesama siswa, pengembangan kemampuan berpikir kritis akan sangat terbatas. Komunikasi satu arah berdampak pada pengetahuan siswa yang hanya terbatas pada apa yang diberikan dan diketahui guru, siswa maupun dengan sumber belajarnya. Siswa kurang terlatih kemandiriannya sehingga siswa hanya akan belajar pada saat dikondisikan guru. Akibatnya, siswa tidak terbiasa dalam memperluas, memperdalam, dan memperkaya pengetahuannya yang pada gilirannya berpengaruh terhadap rendahnya hasil belajar siswa.

Berdasarkan uraian tersebut di atas, maka dapat disimpulkan bahwa terdapat perbedaan hasil belajar antara siswa yang mengikuti pembelajaran dengan metode penemuan terbimbing berbantuan media realita dengan siswa yang mengikuti pembelajaran konvensional.

\section{Perbedaan motivasi berprestasi dan hasil belajar matematika secara simultan antara siswa yang mengikuti pembelajaran dengan metode penemuan terbimbing berbantuan media realita dan siswa yang mengikuti pembelajaran konvensional}

Berdasarkan hasil temuan dalam penelitian ini yang menunjukkan bahwa harga $\mathrm{F}$ untuk Pillai's Trace, Wilks' Lambda, Hotelling's Trace, dan Roy's Largest Root memiliki nilai signifikansi lebih kecil daridapa 0,05. Maka dari itu, harga F untuk Pillai's Trace, Wilks' Lambda, Hotelling's Trace, dan Roy's Largest Root signifikan. Dengan rata-rata skor motivasi berprestasi siswa yang mengikuti pembelajaran dengan metode penemuan terbimbing adalah 189,65 lebih besar daripada skor rata-rata siswa yang mengikuti pembelajaran konvensional yaitu sebesar 143,05, dan rata-rata skor hasil belajar matematika siswa yang mengikuti metode penemuan terbimbing adalah 82, 85 lebih besar daripada siswa yang mengikuti pembelajaran konvensional yaitu sebesar 59,31 dan. Oleh karena itu, dapat disimpulkan bahwa terdapat perbedaan motivasi berprestasi dan hasil belajar matematika yang signifikan antara kelompok siswa yang menggunakan metode pembelajaran penemuan terbimbing berbantuan media realita dengan kelompok siswa yang menggunakan metode pembelajaran konvensional.

Temuan penelitian ini didukung oleh penelitian yang dilakukan oleh Latifa sahara dan Ridwan abdulah Sari (2016) yang hasil penelitiannya menunjukkan bahwa metode penemuan terbimbing memberikan pengaruh yang signifikan terhadap hasil belajar dan aktivitas belajar siswa.

Penerapan metode penemuan terbimbing berbantuan media realita berkontribusi secara signifikan dalam perbaikan proses pembelajaran, khususnya dalam menumbuhkan motivasi berprestasi siswa. Penggunaan media realita dalam pembelajaran mampu meningkatkan motivasi siswa dalam mengikuti pembelajaran. Dalam pembelajaran, aktivitas belajar siswa terdongkrak karena metode penemuan terbimbing menuntut siswa untuk aktif, kreatif dalam mencari dan mengorganisasi informasi, konsep, dan prinsip yang disajikan guru dengan bimbingan guru.

Sementara pembelajaran konvensional selama proses pembelajaran, siswa kurang aktif sehingga pembelajaran berjalan monoton dan kurang menarik perhatian siswa. Hal ini dikarenakan pembelajaran konvensional dimulai dengan penyampaian materi dengan ceramah oleh guru, orientasi dan penyajian informasi yang berkaitan dengan konsep yang akan dipelajari, dilanjutkan dengan pemberian ilustrasi atau contoh soal oleh guru dan tanya jawab, sampai akhirnya guru merasa bahwa apa yang telah diajarkan dapat dimengerti oleh siswa. Guru cenderung memegang kontrol proses pembelajaran sehingga guru lebih aktif sementara siswa relatif pasif menerima dan mengikuti apa saja yang disajikan oleh guru.

Pembelajaran konvensional cenderung menekankan penyampaian informasi yang bersumber dari buku teks, referensi, atau pengalaman pribadi dengan menggunakan teknik ceramah maupun diskusi, sehingga pengetahuan yang akan dipelajari siswa harus disajikan oleh guru perlu memberikan definisi dari konsep yang akan diterima siswa. Suasana pembelajaran konvensional cenderung membosankan di mata siswa sehingga keberhasilan perubahan sikap dan prilaku peserta didik relatif sulit diukur. 
Berdasarkan uraian tersebut di atas, dapat disimpulkan bahwa ada interaksi perbedaan motivasi berprestasi dan hasil belajar matematika antara siswa yang mengikuti pembelajaran dengan metode penemuan terbimbing berbantuan media realita dan siswa yang mengikuti pembelajaran konvensional.

\section{Simpulan dan Saran}

Berdasarkan temuan di atas, dapat disimpulkan bahwa metode penemuan terbimbing berbantuan media realita memberikan pengaruh yang signifikan terhadap motivasi berprestasi dan hasil belajar matematika siswa kelas V SD di Gugus XV Kecamatan Buleleng Kabupaten Buleleng.

Berdasarkan temuan-temuan dan simpulan yang telah dikemukakan di atas, adapun saran yang dapat diajukan dalam penelitian ini adalah sebagai berikut. 1) Pembelajaran dengan metode penemuan terbimbing perlu diperkenalkan kepada guru melalui seminar-seminar, pelatihan-pelatihan maupun dalam pertemuan MGMP agar pembelajaran menjadi PAIKEM, 2) Kepada guru khususnya guru matematika disarankan untuk mencoba menggunakan pembelajaran dengan metode penemuan terbimbing, karena pembelajaran dengan metode ini telah terbukti menjadikan hasil belajar matematika siswa lebih tinggi dari pada siswa yang mengikuti pembelajaran konvensional, 3) Bagi para peminat perlu diadakan penelitian sejenis dengan melibatkan sampel yang banyak, tingkat kelas yang beragam, diharapkan hasil penelitiannya lebih akurat sehingga dapat dipergunakan untuk mengambil suatu kebijakan.

\section{Daftar Rujukan}

Agung, A.A.G. 2011. Metodologi Penelitian Pendidikan. Singaraja: Fakultas Ilmu Pendidikan IKIP Negeri Singaraja.

2017. Pengaruh Matematika Realistik Berbasis Pemecahan Masalah Terhadap Hasil Belajar Matematika Siswa Kelas V SD. Mimbar PGSD. Diakses 3 Juli 2017.

Dantes, N. 2012. Metode Penelitian. Yogyakarta: Andi Offset.

------, 2014. Landasan Pendidikan “Tinjauan dari Demensi Makropedagogis". Singaraja: Universitas Pendidikan Ganesha.

Haryani H., dkk. 2014. "Penerapan Metode Penemuan Terbimbing Pada Pembelajaran Matematika Kelas XI IPA SMAN Lubuk Alung”. Jurnal Pendidikan Matematika, Part 1 Hal. 38-44 Vol. 3 No. 1. Diakses 5 Juli 2017.

Liana, A., dkk. 2015. Pengaruh Metode Pembelajaran Penemuan Terbimbing Terhadap Hasil Belajar Matematika Siswa Kelas VIII SMP Negeri Sidoharjo Tahun Pelajaran 2015/2016. Jurnal Pendidikan dan Pengajaran, Volume 5 Tahun 2015, Diakses tanggal 6 Juli 2017.

Margunayasa, I G., dkk. 2016. "Pengaruh Model Pembelajaran Inkuiri Terbimbing dan Motivasi Berprestasi Terhadap Hasil Belajar Ipa Siswa”. Mimbar PGSD. Diakses 7 Juli 2017.

Marhaeni, A.A.I.N. 2013. Landasan Dan Inovasi Pembelajaran. Singaraja: Universitas Pendidikan Ganesha

Oladipupo B., A. 2015. "Effects of Guided Discovery and ThinkPair-Share Strategies on Secondary School Students' Achievement in Chemistry". Article Education. Diakses 4 Juli 2017.

Olorode, J., dkk. 2016. "Effectiveness of Guided Discovery Learning Strategy and Gender Sensitivity on Students' Academic Achievement in Financial Accounting in Colleges of Education. International Journal of Academic Research in Education and Review. Diakses 7 Juli 2017.

Rebecca, R. 2016. Relationships Among Tasks, Collaborative Inquiry Processes, Inquiry Resolutions, and Knowledge Outcomes in Adolescents During Guided Discovery-Based Game Design in School. Journal of Informations Service. Diakses 7 Juli 2017.

2016. Connecting Student Information Resource Uses to Learning Outcomes in Guided Discoovery-Based Game Design. iConference 2016. Diakses 7 Juli 2017.

Rusman. 2005. "Inisiasi Komputer dan Media Pendidikan". (online). Tersedia: www.geocities.com//novyant/Ss inisiasikomputerdan media pendidikan//.[25 Oktober 2008\}. 